Vol. 1, No. 2, Mei 2020, pp. 11-20

\title{
PENINGKATAN KETERAMPILAN BERBICARA BAHASA ARAB MELALUI METODE BERNYANYI PADA ANAK KELOMPOK B DI PAUD AL-MADANIY GONDANGLEGI-MALANG
}

\author{
Dahlia Amalia ${ }^{1}$, Afifatu Rohmawati ${ }^{2}$ \\ Program Studi Pendidikan Islam Anak Usia Dini,Fakultas Tarbiyah, \\ Institut Agama Islam Al-Qolam Malang \\ launchingdahlia96@gmail.com, afIfaturohmawati@alqolam.ac.id
}

\section{Info Artikel}

Riwayat Artikel

Diterima : 31 Januari 2020

Disetujui : 29 Februari 2020
Kata Kunci :

Ketrampilan Berbicara,

Bahasa Arab, Metode

Bernyanyi

\section{ABSTRAK}

Abstract: Improving Arabic speaking skills through singing method which shows that there are problems in learning Arabic for children who have developed at each school are less attractive. Thus, researchers designed the concept of learning Arabic using the method of singing. This research uses the type of Classroom Action Research (Action Research). Data collection techniques through the application of cycles, and documentation. Based on the findings show that there is an increase in Arabic speaking skills through the method of singing which is shown through an increase in mastery learning with a percentage of $30 \%$. The increase in the first cycle with a percentage of $53 \%$ and an increase in the second cycle with a percentage of $83 \%$. So, the improvement of Arabic speaking skills through singing method in group B children between cycle I to cycle II was 30\%. In the results obtained the singing method is very effective and efficient in improving Arabic speaking skills through memorization techniques.

Abstrak: Peningkatan keterampilan berbicara bahasa arab melalui metode bernyanyi yang menunjukkan bahwa adanya permasalahan dalam pembelajaran bahasa arab terhadap anak yang telah dikembangkan disekolah masing kurang menarik. Sehingga, peneliti merancang konsep pembelajaran bahasa arab dengan menggunakan metode bernyanyi. Penelitian ini menggunakan jenis Penelitian Tindakan Kelas (Action Research). Teknik pengumpulan data melalui penerapan siklus, dan dokumentasi. Berdasarkan hasil temuan menunjukkan bahwa adanya peningkatan keterampilan berbicara bahasa arab melalui metode bernyanyi yang ditunjukkan melalui peningkatan ketuntasan belajar dengan prosentase $30 \%$. Peningkatan pada siklus I dengan prosentase $53 \%$ dan peningkatan pada siklus II dengan prosentase $83 \%$. Maka, peningkatan keterampilan berbicara bahasa arab melalui metode bernyanyi pada anak kelompok B antara siklus I ke siklus II sebesar 30\%. Pada hasil yang di peroleh metode bernyanyi sangat efektif dan efisien dalam meningkatkan keterampilan berbicara bahasa arab melalui teknik menghafal. 


\section{PENDAHULUAN}

Kemampuan berbahasa asing merupakan salah satu potensi yang perlu dimiliki oleh pelajar berdasarkan teknik penerapan melalui proses lisan dan tulis. Penerapan kemampuan bahasa asing kepada anak tentu tidak mudah. Melihat dari segi proses pengajaran tentang konsep bahasa untuk menunjang keterampilan dasar anak ketika berkomunikasi. Komponen penerapan keterampilan berbahasa pada anak usia dini, meliputi (1) keterampilan menyimak merupakan salah satu kemampuan seseorang dalam memahami kata yang dibicarakan oleh mitra bicara untuk saling memahami (mahara al-istima'). (2) keterampilan berbicara merupakan salah satu kemampuan mengungkapkan kata-kata yang ada di pola pikir seseorang berupa ide, pendapat ataupun keinginan (mahara al-kalam). (3) keterampilan membaca merupakan kemampuan yang mengenali dan memahami isi sesuatu yang tercatat serta mencerna di dalam hati maupun pola pikir (mahar alqiraah) dan (4) keterampilan menulis merupakan kemampuan mengutarakan isi pola pikir terutama terletak pada imajinasi yang ingin diutarakan dari menulis katakata hingga terbentuk karangan (mahar al-kitabah) ${ }^{l}$. Hal tersebut terlihat pada keterampilan menyimak dan membaca dikategorikan kedalam keterampilan resertif (al-maharat al-istigobaliyyyah). Sedangkan, keterampilan berbicara dan menulis dikategorikan ke dalam keterampilan produktif (al-maharat al-intajiyyah) yang dapat diterapkan pada lembaga pendidikan anak usia dini.

Lembaga pendidikan anak usia dini yang melaksanakan program pembelajaran bahasa arab bagi anak didiknya melalui media bilingual maupun kegiatan pembelajaran secara langsung. Program bahasa arab ini menjadi salah satu program terpenting dari sekolah untuk menumbuhkan kemampuan daya ingat anak yang belum bisa menguasai kosa kata dalam berbahasa arab, seperti bentuk dari proses pembacaan Al-Qur'an. Teknik dalam menguasai bahasa arab dikembangkan secara bertahap ${ }^{2}$. Penguasaan bahasa arab oleh anak tentu tidaklah mudah membalikan telapak tangan. Ketika saat masa-masa perkembangan proses belajar anak usia dini melalui teknik belajar serayanya bermain. Pada dasarnya seorang guru dalam menerapkan pembelajaran masih cenderung bersifat konvensional. Dimana, anak didik masih mengerjakan buku paket yang sudah disediakan dari sekolah. Akan tetapi, sangat telihat tampaknya mereka merasa jenuh dan akhirnya berpengaruh dengan kemampuan berbahasa arab yang di peroleh. Sehingga, pentingnya guru dalam berinovasi untuk mengkombinasikan bentuk aktivitas belajar anak dengan metode bernyanyi.

Menurut Aisyah,.dkk (dalam Suryaning, 2018) mengatakan bahwa pendidikan anak usia dini merupakan salah satu bentuk penyelenggaraan pendidikan yang menitik beratkan pada peletakan dasar kearah pertumbuhan dan

\footnotetext{
${ }^{1}$ Iskandarwassid, dkk (2006). Strategi Pembelajarn Bahasa, Cetakan VI PT : Remaja Rosdakarya

${ }^{2}$ Muliawan, J. U., (2017). 45 Model Pembelajaran Spektakuler. cetakan I Yogya: karta: Ar-Ruzz Media.
} 
perkembangan kecerdasaan anak dalam mengelolah kemampuan berbahasa maupun berkomunikasi yang akan berdampak pada sosial anak. ${ }^{3}$ Menurut Santrock (dalam Suryaning, 2018) mengemukakan bahwa pendidikan anak usia dini berorientasi kepada anak, segala rancangan aktivitas menekankan pada keterlibatan seluruh anak dengan tujuan memberikan stimulus pada aspek perkembangan nilai dan moral, kognitif, fisik motori, bahasa, sosial dan seni anak. Sehingga, Pembelajaran bahasa arab dapat diorganisasikan sesuai dengan minat-minat dan gaya belajar anak usia dini. ${ }^{4}$

Keterampilan berbicara (mahara al-kalam) merupakan kemampuan lisan yang mengungkapkan kata-kata untuk mengepresikan pikiran berdasarkan ide, pendapat, keinginan, atau perasaan untuk disampaikan kepada peserta didik melalui materi pembelajaran bahasa arab. Selain itu, dalam mengelolah bahasa arab tentu di setiap kalimat memiliki makna yang bersifat meluas. Teknik pengembangan keterampilan berbicara tentu menjadi suatu konsep yang bisa di dengar dan di lihat melalui kemampuan lisan untuk memperoleh kebermanfaatan dalam mengembangkan sistem kinerja otak dan jaringan otot tubuh manusia ketika merespons, seperti proses komunikasi yang dilakukan dengan dua orang atau lebih. Menurut Hermawan, (2011) mengatakan bahwa keterampilan dasar dalam berbicara dapat mengkombinasikan kemampuan fisik, psikologis, neurologis, sematik, dan liguistik sebagai alat manusia yang paling penting saat berkembang di lingkungan sosial..$^{5}$ Sehingga, proses pembelajaran bahasa arab dapat kontribusi dalam menumbuhkan keterampilan dasar anak ketika berkomunikasi untuk menyampaikan pesan melalui teknik bernyanyi.

Metode bernyanyi merupakan metode yang menghubungkan sebuah kalimat dengan tempo nada lagu secara dinamis. Sebab, perlu diketahui bahwa menurut Muliawan, (2017) menyukai intonasi nada dan ritme dengan proses penggabungan hingga membentuk nada yang lebih enak di dengar. Menurut Grace Sudagro sebagai seorang musisi dan pendidik mengatakan,“ dasar-dasar musik klasik secara umum berasal dari ritme denyut nadi manusia. Sehinga, peran besar dalam perkembangan kinerja sinaps-sinaps otak, pembentukan jiwa, karakter, bahkan ragam manusia". Kegiatan penelitian ini menujukkan penerapan musik klasik yang mengandung komposisi nada berfluktuasi antara nada tinggi dan nada rendah akan merangsang kuadran C pada otak. Sampai usia 4 tahun kuadran B dan C pada otak anak-anak akan berkembang hingga $80 \%$ dengan musik. ${ }^{6}$

Menurut Setyoadi (dalam Fadillah,2014) mengatakan bahwa maanfaat penggunaan lagu (menyanyi) dalam pembelajaran meliputi saran relaksi dengan

\footnotetext{
${ }^{3}$ Suryaning 'Peningkatan Kemampuan Kognitif Melalui Permainan "Pasaran” Pada Anak Kelompok B RA AL-Masitoh Gedangan Malang”, skips (IAI AL-QOLAM: Gondanglegi Malang ) Cetakan 12018 halaman 13.

${ }^{4}$ Ibid halaman 14.

${ }^{5}$ Acep Hermawan, metologi pembelajaran Bahasa Arab, ( Bandung : PT REMAJA ROSDA KARYA Desember 2011) halaman 135 dan 136.

${ }^{6}$ Muliawan. Model Pembelajaran Spektakuler, cetakan 1 ( Yogya: karta: Ar-Ruzz Media, 2017), halaman 211 dan 212
} 
menetralisasi denyut jantung dan gelombang otak, menumbuhkan minat dan menguatkan daya tarik pembelajaran, menciptakan proses pembelajaran lebih humanis dan menyenangkan, mengingat materi pembelajaran, membangun retensi dan menyentuh emosi dan rasa estetika, proses interanisasi nilai yang terdapat pada materi pembelajaran dan mendorong motivasi belajar anak. ${ }^{7}$

Strategi penerapannya dalam menggunakan metode bernyanyi melalui proses perencanaan, pelaksanaan, dan pengevaluasian hingga anak memperoleh kebermanfaatannya. Kebermanfaatan proses belajar melalui bernyanyi sama seperti penyampaian pesan berupa materi yang dikemas dengan irama lagu klasik dalam membangun rasa senang, rasa gembira atau sedih bernyanyi sangat memberikan motivasi belajar anak. Pada awal mulanya musik klasik secara umum berasal dari ritme denyut nadi seorang manusia dan musik sangat berperan besar dalam perkembangan otaknya, pembentukan jiwa, karakter, bahkan raga manusia. Sedangkan, musik klasik mengandung banyak ragam yang menekankan pada nada berfluktuasi yang diantaranya, seperti nada tinggi maupun nada rendah akan merangsang kuadran $\mathrm{C}$ pada pertumbuhan otak. Metode bernyanyi dapat membantu mengembalikan daya ingat anak pada materi pembelajaran di sekolah.

Tujuan kegiatan penelitian ini untuk mendiskripsikan penerapan metode bernyanyi dalam meningkatkan kemampuan bahasa arab pada anak dan untuk mendeskripsikan kebermanfaatan metode bernyanyi dalam pembelajaran berbahasa arab pada anak kelompok B di PAUD Al-Madaniy Gondanglegi-Malang.

\section{METODE}

Metode penelitian yang digunakan dalam penelitian ini dengan pendekatan PTK (Penelitian Tindakan Kelas) atau dengan istilah bahasa inggris action research. Penelitian ini tentang peningkatan keterampilan berbicara bahasa arab melalui metode bernyanyi pada anak kelompok B di PAUD Al-Madaniy gondanglegi-malang. PTK merupakan salah satu penelitian yang melibatkan guru dalam situasi pendidikan tententu, memahami tentang praktik yang dilakukan dan situasi-situasi proses pembelajaran yang dilakukan. Menurut Arikunto (2010) mengatakan bahwa PTK memerlukan 3 tahap sesuai dengan prosedure yang berbentuk pra tindakan siklus, siklus I dan siklus II dalam menggunakan metode penelitian PTK meliputi planning, action \& observation, dan reflection. kemudian berputar - terjadi perbaikan atau peningkatan yang diharapkan. Penelitian ini dilaksanakan selama lima kali pertemuan. ${ }^{8}$

Subjek penelitian ini dilakukan di PAUD Al-Madaniy gondanglegimalang dengan target penelitian kepada anak kelompok B dengan analisa

\footnotetext{
${ }^{7}$ Muhammad Fadillah, Desain Pembelajaran PAUD Cetakan Ke 1 (Jogjakarta: Ar-Ruzz Media, 2014) halaman 176.

${ }^{8}$ Arikunto, S.(2010). Prosedur Penelitian Suatu Pendekatan Praktik. Jakarta: Rineka Cipta
} 
kemampuan anak dengan karakteristik anak yang berbeda-beda dalam minat keterampilan dasar dalam berbicara bahasa arab di sekolah.

Teknik pengumpulan data yang digunakan dalam penelitian PTK melalui teknik observasi, wawancara, unjuk kerja, dan dokumentasi yang dilakukan oleh peneliti kepada kepala sekolah, guru, dan anak. Subjek utama dalam penelitian PTK tertuju pada peningkatan keterampilan berbicara anak kelompok B melalui metode bernyanyi. Sehingga, strategi pembelajaran yang telah direncanakan harus memiliki ketercapaian hasil yang sesuai dengan prosedure. Adapun teknik analisis data secara deskriptif - kuantitatif, Salah satu rincian analisis data kuatitatif berupa deskriptif yang sesuai dengan analisis data kuantitatif berupa perhitungan angka melalui indikator keberhasilan minat keterampilan berbicara sebagai data penelitian.

Analisis data melalui teknik observasi yang dilakukan melalui proses pengamatan melalui tiga komponen yaitu ruang, subjek yang di teliti dan proses kegiatan. Observasi tentunya dilakukan secara langsung kepada guru kelas dengan pengamatan perkembangan anak dalam proses kegiatan pembelajaran. Deskripsi pada indikator keberhasilan meningkatkan minat keterampilan berbicara yang telah dinilai oleh observator dan didampingi oleh kepala sekolah di PAUD Al-Madaniy melalui hasil observasi pada tahap siklus I dan siklus II.

Berdasarkan paparan diatas pada tindakan setiap siklus dalam penelitian ini dinyatakan berhasil jika di dalam kegiatan belajar $75 \%$ dari 11 anak kelompok B di PAUD Al-Madaniy Dusun Boro Panggungrejo Gondanglegi-Malang mengalami peningkatan keterampilan berbicara bahasa arab melalui metode bernyanyi pada kriteria perkembangan sangat baik (SBS).

\section{HASIL DAN PEMBAHASAN}

Hasil paparan data yang menerapkan metode bernyanyi untuk meningkatkan keterampilan berbicara bahasa arab anak kelompok B di PAUD AlMadaniy di atas. Maka, dapat disimpulkan dalam temuan-temuan dari analisis kegiatan penelitian. Secara umum, kegiatan metode bernyanyi dapat meningkatakan keterampilan berbicara bahasa arab anak kelompok B di PAUD AlMadaniy Gondanglegi-Malang. Peningkatan kualitas tersebut dipaparkan dengan data di setiap siklus secara teperinci.

Pertama, dilakukannya keterampilan berbicara bahasa arab dengan metode bernyanyi membuat anak-anak senang serta gembira untuk melafadzkan kosakata dan melalukan kegiatan. Kedua, Perkembangan keterampilan berbicara bahasa arab melalui metode bernyanyi berkembang dengan optimal, khususnya kemampuan melafadzkan kosa kata bahasa arab. Ketiga, Secara umum kegiatan bernyanyi di PAUD Al-Madaniy Gondanglegi-Malang dapat meningkatkan kualitas proses dan hasil pembelajaran melafadzkan kosakata bahasa arab.

Pada analisis kegiatan awal pembelajaran menggunakan pendekatan kegiatan kreatif, penulisan kosakata bahasa arab dan bernyanyi. Hal ini sesuai 
dengan pembelajaran anak. Tujuannya saat proses pembelajaran berlangsung diharapkan dapat tercipta suasana belajar di kelas secara menyenangkan dan anakanak bisa melafadzkan kosakata yang benar dan fasih. Dengan kegiatan pembelajaran yang sesuai dengan rancangan kegiatan harian (RPPH) yang telah dipersiapkan. Anak-anak mulai bersemangat dan senang dalam melakukan kegiatan bernyanyi namun belum maksimal hasilnya.

Berdasarkan hasil rekapitulasi penilaian pada siklus I dalam kegiatan pembelajaran bahasa arab pada analisis awal ini dan ditemukan adanya meningkatan keterampilan berbicara bahasa arab 53\% (6 dari 11 anak yang ada). Dengan data tersebut, maka peningkatan keterampilan berbicara bahasa arab melalui metode bernyanyi belum berhasil maksimal. Pada pembelajaran tersebut masih menggunakan pendekatan yang sama yaitu kreatif dalam konteks penulisan kosakata bahasa arab melalui bernyanyi. Hal ini sesuai dengan tujuan proses belajar anak. Tujuan untuk menciptakan suasana belajar yang menyenangkan melalui melafadzkan kosa kata dalam bahasa arab.

Hasil rekapitulasi penilaian pada siklus II dalam kegiatan pembelajaran bahasa arab dengan hasil data yang di peroleh dari hasil penelitian dan ditemukan adanya meningkatan keterampilan berbicara bahasa arab dibandingkan sebelum pelaksanaan. analisis awal sebelum pelaksanaan kegiatan penelitian yang dilakukan di lingkungan sekolah, ketuntasan proses belajar anak dalam peningkatan keterampilan berbicara bahasa arab 53\% (6 dari 11 anak yang ada). Setelah, tahap pelaksanaan dengan analisis pada ketuntasan proses belajar anak dalam melafadzkan kosakata bahasa arab sebesar 83\% (10 dari 11 siswa yang ada). Berdasarkan data tersebut, maka peningkatan keterampilan berbicara bahasa arab melalui metode bernyanyi dari pelaksanaan siklus awal sampai akhir siklus terakhir sebesar $30 \%$.

Hasil data tersebut dapat disimpulkan bahwasannya peningkatan keterampilan berbicara bahasa arab melalui metode bernyanyi pada anak kelompok B PAUD Al-Madaniy Gondanglegi-Malang dalam evaluasi secara keseluruhan telah berhasil semaksimal mungkin. Kegiatan refleksi ini akan dikemukakan beberapa hal tentang proses pelaksanaan peningkatan keterampilan berbicara bahasa arab untuk mengembangkan kemampuan berbicara bahasa arab melalui metode bernyanyi anak kelompok B. Pelaksanaan metode bernyanyi pada analisis siklus I dilaksanakan pada 5 kali pertemuan dan terlaksana kurang baik. Namun, data yang diperoleh dari hasil observasi terhadap pembelajaran terdapat beberapa kekurangan pada waktu guru melakukan pembelajaran pada peningkatan keterampilan berbicara bahasa arab yaitu dalam melafadzkan kosakata kurang jelas, dan guru kurang memberi motivasi belajar pada anak-anak. Sehingga, hasil ratarata masih belum mencapai hasil yang begitu maksimal.

Pada bagian refleksi analisis II akan dijelaskan beberapa hal tentang hasil proses pelaksanaan pembelajaran keterampilan berbicara bahasa arab melalui metode bernyanyi untuk meningkatkan kemampuan keterampilan berbicara bahasa 
arab pada anak pada analisis II sudah lebih baik dari pada analisis I. Semua tujuan pembelajaran terpenuhi. Kemampuan keterampilan berbicara bahasa arab yaitu mengenali berbagai kosakata bahasa arab, karya, dan nyanyian bahasa arab serta menunjukan kosakata yang benar dengan menggunakan media.

Pada melakukan keterampilan berbicara bahasa arab anak kelihatan senang dan gembira, semua anak melafadzkan tersebut tanpa bantuan guru. Hasil kemampuan keterampilan berbicara bahasa arab dengan bernyanyi tingkat kemampuan anak lebih terlihat pada analisis siklus I dibanding analisis siklus II pada table 1.1, sebagai berikut:

Tabel 1.1 lembar hasil penilaian analisis siklus I dan siklus II

\begin{tabular}{cccc} 
No & Analisis & Hasil (\%) & Prosentase peningkatan \\
1 & Siklus I & $53 \%$ & Selisih $83 \% 53 \%=30 \%$ \\
2 & Siklus II & $83 \%$ & \\
\hline & Hasil tabel diatas dapat disimpulkan bahwa peningkatan dari siklus I ke
\end{tabular}
siklus II adalah 30\%, berikut rekapitulasi tabel yang dapat digambarkan melalui diagram pada gambar 1.1, sebagai berikut:

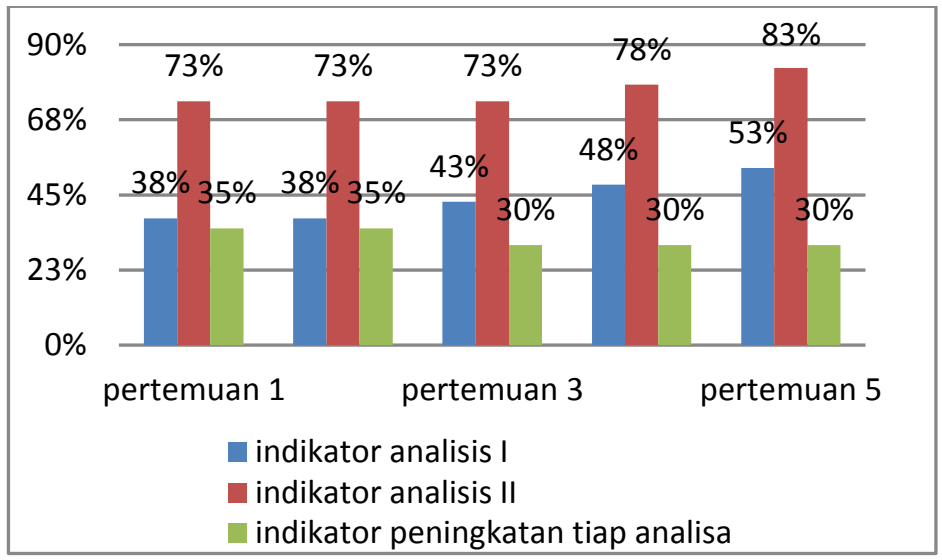

\section{Gambar 1.1 Diagram rekapitulasi siklus I dan siklus II}

Berdasarkan hasil yang telah di capai pada analisa siklus I dan siklus II dapat disimpulkan bahwa kterampilan berbicara bahasa arab melalui metode bernyanyi pada anak usia 4-5 tahun melalui kegiatan bernyanyi telah mengalami peningkatan. Anak-anak mulai menggeneralisasi satu situasi ke situasi lainnya.

Metode bernyanyi merupakan salah satu metode mengembangkan kemampuan bahasa anak. Dalam hal ini anak-anak ikut menyanyikan lagu yang di ajarkan secara berulang-ulang, tanpa mereka sadari mereka telah menyerat materi yang diajarkan dan secara tidak langsung akan menerangkan perkembangan berbahasa anak. ${ }^{9}$ Dan anak-anak semakin senang dan mudah saat melafadzkan kosa kata bahasa arab atau meningkatan keterampilan berbicara bahasa arab dengan

\footnotetext{
${ }^{9}$ Muhammad Fadila dan Lilif Mualifatu Khorida. Pendikan Karakter Anak Usia Dini, (Yogyakarta: Ar- Ruzz Media, 2013) Halaman 162.
} 
adanya metode bernyanyi pada usia 4-5 tahun, saat anak-anak prasekolah sudah memanipulasi lingkungan sekolah dan menemukan ide dan hal-hal yang baru.

Menurut Vygotsky dalam Wolfolk (dalam Susanto, 2011) menyatakan bahwa bahasa merupakan alat untuk mengepresikan ide dan bertanya, dan bahasa juga menghasilkan konsep dan kategori-kategori untuk berfikir. ${ }^{10}$ Sehingga, anakanak mampu mengepresikan kosakata bahasa arab yang benar dan fasih sesuai dengan ide, pola piker, daya tangkap dalam berproses untuk mengembangkan pengetahuannya.

Menurut Syaodih bahwa aspek bahasa berkembang dimulai dengan peniruan bunyi dan merabah. Perkembangan selanjutnya berhubungan erat dengan perkembangan kemempuan intelektual dan sosial. Bahasa merupakan alat untuk berpikir. Berpikir merupakan suatu peroses memahami dan melihat hubungan. Proses ini tidak dapat berlangsung dengan baik tanpa alat bantu, yaitu bahasa. Bahasa juga sebagai alat berkomunikasi dengan orang lain. Kemudian, berlangsung dalam suatu interaksi sosial. ${ }^{11}$ Pada usia PAUD (4-5 tahun) anak sudah bisa melafadzkan kosa kata bahasa arab seperti (mata/ainun, telinga/uzunun, mulut/famun), serta bercakap-cakap antar teman maupun guru sesuai kegiatan hari ini.

Data awal yang diperoleh dengan ketuntasan belajar sebesar $30 \%$ pada prasiklus, prosentase meningkat sebesar 53\% pada analisis siklus I, dan prosesntase meningkat pada analisis siklus II sebesar 83\%. Maka, peningkatan keterampilan berbicara bahasa arab melalui teknik bernyanyi pada anak kelompok B antara hasil siklus I ke siklus II terlihat memiliki peningkatan yang sangat signifikan dengan prosentase hasil akhir sebesar 30\%. Hal tersebut menjadi salah satu proses evaluasi pembelajaran yang penting dilakukan oleh kepala sekolah dan guru bahwasannya penerapan aktivitas dengan menggunakan metode bernyanyi memiliki kontribusi dalam mengembangkan keterampilan berbicara anak. selain itu, memiliki keefektifan dan keefisiensian dalam penggunaan waktu lebih terorganisir secara menyenangkan melalui teknik bernyanyi tanpa adanya tekanan ketika belajar bahasa arab pada anak usia dini.

\section{KESIMPULAN DAN SARAN}

Berdasarkan hasil penelitian dan pembahasan dapat disimpulkan bahwa meningkatkan keterampilan berbicara bahasa arab metode bernyanyi pada anak kelompok B di PAUD Al-Madaniy Dusun Boro Desa Panggungrejo Gondanglegi Malang. Adanya penerapan metode bernyanyi untuk meningkatakan keterampilan berbica bahasa arab pada anak kelompok B. Ketika proses mengenalkan hurufhuruf hijaiyah dengan berbagai media seperti gambar mulut dengan menempelkan kolase pada gambar mulut, berhitung dengan angka bahasa arab serta

\footnotetext{
10 Ahmad Susanto, Perkembangan Anak usia Dini Pengantar dalam Berbagai Aspeknya, Cetakan 1 (Jakarta: Kencana 2011), halaman 73.

${ }^{11}$ Ibid halaman 74.
} 
menjumlahkan angka-angka bahasa arab selain itu juga menyanyikan lagu bahasa arab yang benar dan fasih serta mengulang-ulang kembali sesuai dengan tema hari ini.

Penerapan metode bernyanyi terbukti dapat meningkatkan keterampilan berbica bahasa arab pada anak Kelompok B PAUD Al-Madaniy Dusun Boro Desa Panggungrejo Gondanglegi Malang, yang terlihat dari antusias anak dan mereka merasa senang dengan penerapan metode bernyanyi dalam meningkatkan keterampilan berbicara bahasa arab yang benar dan fasih dalam membaca ALQur'an. Hal ini terlihat dengan adanya peningkatan saat proses belajar di kelas pada pertemuan pada kedua siklus pada akhir siklus I dan siklus II. Dimana, pada siklus I ketrampilan berbicara anak sebesar 53\% dan pada siklus II sebesar 83\% melalui penggunaan metode bernyanyi dapat peningkatan ketrampilan berbicara bahasa arab. Hal itu menunjukkan telah tercapai ketuntasan yang diharapkan sesuai dengan kriteria ketuntasan yang ditetapkan. Peningkatan dari analisis I ke analisis II sebesar $30 \%$.

Berdasarkan hasil pembahasan dapat disimpulkan oleh peneliti melalui beberapa saran sebagai berikut Pertama, hendaknya guru menggunakan metode bernyanyi yang lebih kreatif serta menyanyikan lagu yang bagus sehingga anakanak ditak merasa bosan dengan nyanyia itu saja saat peroses belajar. Kedua, seharusnya guru bisa melafadzkan kosakata bahasa arab dengan baik dan fasih waktu proses belajar agar anak-anak bisa menirukan ketika mimic wajah saat melafadzkan kosakata bahasa arab benar dan fasih.S

\section{DAFTAR RUJUKAN}

Arikunto, S.(2010). Prosedur Penelitian Suatu Pendekatan Praktik. Jakarta: Rineka Cipta

Fadillah, M dan Khorida, L. M., (2014). Pendidikan Karakter Anak Usia Dini. Cetakan I. Jogjakarta: Ar-Ruzz Media.

Fadilah, M., (2014). Desain Pembelajaran PAUD, Cetakan 2 Yogyakarta: Ar-Ruzz Media.

Hermawan, A., (2011). metologi pembelajaran Bahasa Arab. Cetakan I. Bandung: PT Remaja Rosda Karya

Iskandarwassid, dkk (2006). Strategi Pembelajarn Bahasa, Cetakan VI PT : Remaja Rosdakarya

Iskandar, B., dkk (2017). Modul Pengembangan Keprofesian Berkelanjutan. Cetakan II Bandung: PPPPTK dan PLB. 
Muliawan, J. U., (2017). 45 Model Pembelajaran Spektakuler. cetakan I Yogya: karta: Ar-Ruzz Media.

Maryam, M., (2012). Al-Qur'an dan terjemah. Jakarta: Al-Fatih.

Suryaning, (2018). "Peningkatan Kemampuan Kognitif Melalui Permainan "Pasaran" PadaAnak Kelompok B RA AL-Masitoh Gedangan Malang",. Skips. Malang: IAI AL-QOLAM.

Sumardi, M., (1974). Pedoman Pengajaran Bahasa Arab. Cetakan I. Jakarta : Pada Perguruan Tinggi Agama / I.A.I.N

Susanto, A., (2011). Perkembangan Anak usia Dini Pengantar dalam Berbagai Aspeknya. Cetakan 1 Jakarta: Kencana

Sugiono, (2014). Metode Penelitian Kuantitatif, dan R\&D: Teknik Pengumpulan Data. Cetakan XX Bandung: CV. Alfabeta

Yamin, M., dkk (2013). Panduan PAUD Pendidikan Anak Usia Dini. Cetakan 1 Caung : Persada Press Group 